\title{
CO WLAŚCIWIE SPRAWIA, ŻE DZISIEJSZE MIASTA SĄ TAK ODMIENNE, TAK POCIĄGAJĄCE? MIEJSKOŚĆ (PO)NOWOCZESNA
}

\section{Streszczenie}

Posługując się poetyckim studium historii miast zaproponowanym przez Wystana Hugh Audena, stawiamy tezę o głęboko polemicznym charakterze miasta. Żywiołem polis jest polemos, spór, konflikt, który w długiej historii miast przybierał postać dychotomicznego napięcia - między posiadającymi a nieposiadającymi, arystokratami i sankiulotami. Tak długo, jak napięcie to zachowa ów binarny kształt, miasto będzie powielało swą dotychczasową historię z wszystkimi jej błędami. Współczesne miasto tworzy zbyt wiele elementów, zbyt mocno wirtualne interweniuje w realne, by dało się myśleć o przyszłości w kategoriach prostych opozycji. Jak proponuje Gilles Deleuze, model dotychczasowy opierający się na owych opozycjach wraz z podtrzymującym i wyostrzającym je systemem nakazów i zakazów powinien zostać zastapiony przez model, w którym główną rolę odgrywają pragnienia, afekty i marzenia jednostek; te zaś nie poddadzą się dialektycznej analizie. Stawką jest więc miasto tyleż rzeczywiste, co wyobrażeniowe, choć to ostatnie określenie nie oznacza, że całkowicie nierealne i wymyślone. Miasto traktowane „osobiście" (tak nazywa Andrew Merrifield stanowisko Guy Deborda i Louisa Chevaliera): miasto nabierajace ciała, to znaczy jawiące się nam warstwowo i gruboziarniście. Miasto znane nam osobiście, co wskazuje nie tylko na mnie jako na osobę, ale przede wszystkim na miasto zyskujące osobowy status,

* Prof. zw. dr hab., Katedra Literatury Porównawczej; e-mail: tadeuszslawek@poczta.onet.pl 
z jego historią, widocznymi i niewidocznymi dziejami, śladami, znakami, które skryły się w podświadomości czasu.

Słowa kluczowe: miasto, racjonalność, afekt, wyobraźnia, zabawa

1.

W 1956 roku Richard Hamilton wziął udział w wystawie This is Tomorrow w galerii Whitechapel, gdzie pokazał stworzony wraz z architektem Johnem Voelckerem $\mathrm{i}$ artystą Johnem McHalem kolaż, którego tytuł, z jedną istotną zmianą, pozwalam sobie pożyczyć dla niniejszego eseju. Dzieło Hamiltona traktuje o „mieszkaniach”; zamieniając „mieszkania” na „miasta” dokonujemy pewnego przewartościowania - indywidualne i zamknięte w prywatności ustępuje przed zbiorowym i publicznym. Hamilton konstruuje wizualną opowieść o świecie, który dźwigając się z wojennej ruiny, otworzył nowe możliwości, ale i nauczył się manipulowania potrzebami człowieka, wpisując go tym w nieubłaganą logikę rynku i konsumpcji. Uważne spojrzenie dostrzeże obecność zewnętrznego świata: na suficie widnieje obraz ziemi fotografowanej z kosmosu, na rozłożonym na podłodze dywanie ludzie przechadzają się po plaży; to, co dzieje się we wnętrzu, jest wyrazistym przykładem współczesnego, (po)nowoczesnego sposobu organizowania życia. A zatem chodzi też o miasto i o wolność.

Gdyby nie ironiczny dystans artysty mógłby on podpisać się pod inwektywami, jakie Thomas Mann kazał wygłosić Naphcie w słynnej dyskusji z Settembrinim:

...sprawa wolności czy sprawa miast, jak można konkretniej powiedzieć, jakkolwiek jest w najwyższym stopniu moralną, to historycznie jest związana z nieludzkim zwyrodnieniem moralności gospodarczej, ze wszystkimi okropnościami nowożytnego handlarstwa i spekulacji, z szatańskim panowaniem pieniądza i interesów [Mann 2016: 462].

Chodzi więc o przyszłość (przypomnijmy tytuł całej wystawy), a dokładniej o pytanie, czy przyszłość rodzaju ludzkiego (patos tego sformułowania wydaje się uzasadniony faktem, że mężczyzna i kobieta Hamiltona, nadzy, znajdują się w przetworzonej scenie rajskiej obfitości, a więc sprawa ma także wymiar teologiczny) da się określić w kategoriach ludzkich potrzeb konsumenckich, stwarzanych i zaspokajanych w sposób nadający naszemu życiu pozór bycia „pociagającym” i „odmiennym” przez osiagnnięcia nauki, techniki i tego, co Jan Patočka nazwał najogólniej „matematycznym przyrodoznawstwem”. Pytamy o przyszłość, która w dużej mierze dotyczy przyszłości miast. Pytamy w obliczu niepokojów, dramatów i rozterek współczesnego świata, świata, w którym - mimo 
naszych wysiłków - wciąż narasta cierpienie. W Czarodziejskiej górze odnajdziemy to właśnie pytanie, będące $\mathrm{w}$ istocie zarzutem, a może wręcz oskarżeniem: „słusznie zarzucamy naszemu obecnemu stanowi kultury, że niedostatecznie spełnia on nasze wymagania dotyczące uszczęśliwiającego ładu życia, że nie sprzeciwia się istnieniu cierpienia, którego przypuszczalnie dałoby się uniknąć..." [Mann 2016: 286].

2.

W napisanym w czerwcu 1949 roku wierszu Ku pamięci miasta Wystan Hugh Auden kreśli swoistą filozofię miasta i trajektorię jego historycznego rozwoju. Spróbujmy prześledzić ją w upraszczającym i zapewne niedopuszczalnym skrócie. Najpierw pojawia się Nowe Miasto, the New City, wyrastające z napięcia między świeckimi i świętymi sposobami konfigurowania świata i jego zdarzeń. Jest więc papież Grzegorz i Cesarz, i to z ich konfliktu, upon their opposition, wyrasta miasto, które niemal naturalnie obdarza podwójnym znaczeniem to, co w nim zachodzi i to, co miasto stanowi jako własne prawo, the facts, the acts of the City bore a double meaning. To, co fizyczne nigdy nie jest nim bez reszty, ulotne więzi przybierają postać permanentną, i - co bodaj najistotniejsze jako mechanizm konstytuowania się miasta - szuka ono swej tożsamości, określając się przeciwko siłom znajdującym się poza jego murami: „Oblicza niewiernych w śnie gniewnym / Zastąpiły dotychczasowych przeciwników rodu" [Auden 1991: 591]. Miasto jest tym, czym jest, bowiem konfiguruje się wedle modelu podwójnego napięcia: jedna linia łączy i dzieli świętą i świecką władzę, druga stwarza między nimi pomost porozumienia dzięki poczuciu istnienia wspólnego, zewnętrznego wroga. Miasto jednoczy się, zespajając materialne budowle (zamek, katedra) z ich powszechnie uznanym symbolicznym znaczeniem, czyniąc to wobec przeciwnika, którym jest to, co nie jest miastem, tym miastem. Właśnie wspólny przeciwnik jednoczy świeckie i boskie, to zaś wzmacnia i sakralizuje władzę. Thomas Mann w Czarodziejskiej górze czyni z Grzegorza protoplastę ruchów komunistycznych. W zabiegach papieża chodzi nie o samą władzę, lecz o „czasowe usunięcie przeciwieństwa między duchem a władzą”. Państwowość polega na „przejściu, transcendencji, znaczeniu państwowości”. „Proletariat podjął dzieło Grzegorza, ma jego entuzjazm dla praw boskich i tak samo jak on nie będzie mógł ręki cofnąć przed krwią. Zadaniem jego jest wzbudzenie grozy dla zbawienia świata i dla osiagnięcia tego, co było celem Zbawiciela: bezpaństwowego i bezklasowego synostwa bożego" [Mann 2016: 461]. 
3.

To podwójne napięcie stabilizuje ekonomię i administrację miasta, kwitną w nim „skrybowie i karczmarze”, a konsekwentna polityka polegająca na kreowaniu wroga pozwala na rozszerzenie wpływów oddziaływania miasta. W ten sposób tworzy się sieć miast zawdzięczająca istnienie wspólnemu wrogowi: „dotąd nieufne plemiona łączą się / By wyrwać Jeruzalem z władzy tępego boga". Drugi etap dziejów miasta formuje ich związki, które będą trwały dopóty, dopóki da się podtrzymać istnienie przeciwnika oraz sublimować jego pozycję (bóg i Jeruzalem); nie chodzi więc o zwykłe zmagania militarne, lecz o walkę o stusznego boga i zniszczenie boga niewłaściwego oraz o odzyskanie miasta będącego jego stolicą i powierzenie go jako lenno bogowi jedynemu, czyli naszemu. Działanie takie wymaga precyzyjnych kryteriów oceny sytuacji i silnie wspólnotowych wartości pozwalających na zniwelowanie idiosynkratycznych, subiektywnych metod konfigurowania świata. Nowoczesnym odpowiednikiem takiej łączliwości miast szukających porozumienia nie tylko z bezpośrednim otoczeniem, ale nawet z przestrzennie odległym sojusznikiem jest przepływowa ekonomia globalna. Według Manuela Castellsa „względna ważność relacji miasto-region wydaje się zmniejszać w porównaniu z ważnością relacji, które wiążą ze sobą różne miasta odmiennych regionów i krajów. [...] Nowe formy działalności koncentrują się na poszczególnych biegunach, a to oznacza wzrastające niewspółmierności między biegunami miejskimi i ich odpowiednim zapleczem krajowym" [Castells 2008: 385]. Cechą Miasta Przytomnego, Sane City, jest centryczność oparta na wspólnym interesie ideologicznym i pozostających w jego służbie wymogach racjonalności, dlatego „surowi logicy walczą, by myśl / Ocalić przed ekscentryzmami osobniczych mózgów”. W Mieście Przytomnym jednostka zostaje postawiona w potencjalny stan oskarżenia jako chwilowo „uśpiony” czynnik ekscentryczny, który w każdej chwili może łatwo stać się przedmiotem podejrzeń i penalizacji.

4.

Mariaż ideologii i praktyk dyscyplinujących prowadzi do sytuacji, w której miasto staje się działającą w oparciu o rachunek ekonomiczny maszyną. Nowoczesność rozpoczyna się od momentu, w którym możliwe staje się przeliczanie niepoliczalnych wartości na nader policzalne korzyści. Na tym polegało odkrycie Martina Lutra: w jego analizie miasto to „maszyna, która, gdy jej zapłacić/Sprawnie przebacza i zbawia". Miasto Grzechu, The Sinful City, to miasto, w którym 
obywatelskość została wyskalowana wedle współczynników bogactwa i wpływu politycznego. Ideałem życia miejskiego jest obywatel skupiający się na pomnażaniu bogactwa, a zatem dopasowujący się do obowiązującego sposobu organizacji świata. Tak bycie (w znaczeniu jego jednostkowej i społecznej dramaturgii) staje się o-byciem (dostosowywaniem się do przyjętego i rekomendowanego sposobu życia), obywatelskość przekształca się w akumulację dóbr pod dyktando wymagań rynku i wymuszanych przezeń konformistycznych zachowań. U Audena czytamy - „Wspólne bycie to miasto, które się bogaci”, civility a city grown rich. To właściwy moment, by przypomnieć dictum Guy Deborda: „Nie ma nic głupszego niż obecna organizacja życia" [Merrifield 2016: 82].

\section{5.}

Dalszy bieg wydarzeń zaowocuje Miastem Rozumu, the Rational City, zideologizowanym miastem jednej hegemonicznej idei rygorystycznie narzucającej obowiązujący porządek rzeczy (,historia maszeruje w rytmie świetlanej idei”). Aby podtrzymać sprawne działanie tego systemu, niezbędne jest ciagłe eksplorowanie terenu w poszukiwaniu nowych możliwości życia przedstawianego jako życie pełne „sukcesu”. Dawniej eksploracja ta była geograficzna, w miarę zapełniania się białych plam kolorami stawała się strategią uprzywilejowywania wartości dodanej kosztem wartości użytkowej. Walter Benjamin lokuje początki tego procesu w okresie pierwszych wystaw narodowych, które poprzedziły wystawy światowe. Jak pisze, pierwsza z nich w roku 1798 w Paryżu ,wzięła się z pragnienia, by zabawić klasy robotnicze, stając się dla nich świętem emancypacji”. Akcent niewatpliwie pada na czasownik zabawić, bowiem chodzi o stworzenie sytuacji, w której przy wszelkich pozorach zmian wszystko pozostaje w gruncie rzeczy takie samo. Benjamin zauważa dalej: „Człowiek poddaje się manipulacjom tego przemysłu, rozkoszując się wyobcowaniem od samego siebie i innych” [Benjamin 1975: 170, 171].

Tak biegnie ewolucja oświeceniowej nadziei na zbudowanie społeczeństwa: od Kantowskiego przełomu pełnoletniości wyemancypowanego rozumu jednostki do hegemonii rozumu zbiorowego zorganizowanego zgodnie $\mathrm{z}$ wymaganiami kapitalistycznego rynku i produkcji. W nomenklaturze Audena, aby podtrzymać swe istnienie, Miasto Rozumu staje się rychło Miastem Błyskotek (the Glittering City), którego geografia stanowi niemal Joyce'owską parodię Homerowskiej Odysei. Mieszkaniec miasta porusza się bezładnym szlakiem, którego nader nieprecyzyjna mapa obejmuje takie topoi, jak „Przylądek Galopującej Konsumpcji” (Cape of Consumption), „Morza Ochlaptusów” (Tosspot Seas), skaliste 
„Wyspy Bełkotu” (Gibbering Isles). W tym dyscyplinującym porządku miasta kryje się jednak głęboki wstrząs, kryzys doświadczenia, które György Lukacs nazwał „transcendentalną bezdomnością”, będącą - paradoksalnie - efektem nadmiernych zabiegów udomowienia życia. Ów kryzys nowoczesności, tektoniczny wstrząs rujnujący Miasto Błyskotek, uświadamiał rozdźwięk między człowiekiem i światem, ale także między człowiekiem i jego czasem. Przywołajmy samego Lukacsa:

Szczęśliwe czasy, dla których niebo gwiaździste jest mapą dróg otwartych, rozświetlonych, zapraszających do przebycia. Wszystko zdaje się nowością - ale nowością znajomą, przygodą - lecz i własnością. Świat tak rozległy wydaje się domem, bo ogień płonący w duszy jest tej samej natury, co gwiazdy [Lukács 1968: 21].

Świadomość ta oznacza, że, jak ujmie to Auden, mieszkańcy miasta „umierali samotni, niespełnieni”, aczkolwiek dokonując podstawowego odkrycia: zgodnie z ustalonym porządkiem rzeczy wysiłki utrzymywania wszystkiego $\mathrm{w}$ niezmienionym stanie przy wszelkich pozorach zmiany, mające na celu rozwianie jakiejkolwiek tajemniczości właściwej życiu, teraz niemal doskonale sfetyszyzowanemu, okazują się nieskuteczne. To, co nieznane, ukryte, co posługuje się innym językiem i wierzy w innych bogów, jest ciagle TAM, w dalekiej przestrzeni, w ten sposób nadal, często wbrew wykluczającym zabiegom ideologicznej maszyny, konstytuując miasto. „Poznali zakazane, / ukryte, dzikie pola" i ta wiedza okazuje się nieodzowna dla powstania Miasta Świadomego, the Conscious City, będącego miastem „wiernych bez wiary”, faithful without faith . Teraz miasto oznacza otwarcie pola krytycznej refleksji, na którym jednostka może konstruować swój własny los. Takie otwarcie jest do pomyślenia dopiero wtedy, gdy człowiek odzyskuje sposobność prowadzenia sumiennej rozmowy z samym sobą. Akcentujemy ową sumienność, bowiem, jak przekonuje Hannah Arendt, jest ona warunkiem społecznej przemiany, polegającej na odzyskiwaniu poczucia obywatelstwa. Kontestując totalitarne skłonności systemów społecznych, Arendt pisze, że „możemy łatwo zaświadczyć, że tam, gdzie człowiek nie ma zapewnionej choćby odrobiny bycia z samym sobą, tam zanika sumienie, nie tylko w sensie świeckim, ale i we wszystkich religijnych odmianach. [...] Nie można zachować sumienia, jeśli nie ma się szansy na prowadzenie dialogu z samym sobą, to znaczy jeśli się jest pozbawionym samotności, nieodzownej dla wszelkich form myślenia" [Arendt 2005: 57]. 
6.

Co wynika z owego poetyckiego studium dziejów miasta, które sam Auden nazywa miastem post-Wirgiliuszowym (the Post-Vergilian City), i jakie wyciagamy $\mathrm{z}$ niego nauki? Po pierwsze, miasto ma polemiczny charakter: żywiołem polis jest polemos, spór, konflikt, który w długiej historii miast przybierał postać dychotomicznego napięcia - między posiadającymi a nieposiadającymi, arystokratami i sankiulotami. Tak długo, jak napięcie to zachowa ów binarny kształt, miasto będzie powielało swą dotychczasową historię z wszystkimi jej błędami. Współczesne miasto tworzy zbyt wiele elementów, zbyt mocno wirtualne interweniuje w realne, by dało się myśleć o przyszłości w kategoriach prostych opozycji. Jak proponuje Gilles Deleuze, model dotychczasowy, opierający się na owych opozycjach, z podtrzymującym i wyostrzającym je systemem nakazów i zakazów, powinien zostać zastąpiony przez model, w którym główną rolę odgrywają pragnienia, afekty i marzenia jednostek, te zaś nie poddadzą się dialektycznej analizie [Deleuze 2017]. Z tej perspektywy miasto jest uporządkowaną administracyjnie i topograficznie scena, na której każdy z nas usiłuje rozegrać swoje życie kształtowane przez przygodne, a zatem często bezładne, okoliczności. Trafnie ujmuje to Italo Calvino: „Symbolem bardziej złożonym, który lepiej pozwolił mi wyrazić napięcie między geometrycznym sposobem myślenia a gmatwaniną ludzkich istnień, jest miasto" [Calvino 2009: 82].

Po drugie, niezbędny staje się stan czujności stawiający nas w gotowości do wyrażenia sprzeciwu wobec dialektycznego strukturowania miasta. W praktyce prowadzi to do nieufności wobec nasilających się prób przejmowania władzy w mieście przez osoby z nadania partyjnego. Mechanika ich działania jest bowiem mechaniką działania partii, a nie miasta. Stąd konieczność i potrzeba wspierania niepartyjnych, obywatelskich kandydatur w wyborach samorządowych. A także uważnego studiowania przykładów tego rodzaju działalności, w której logika obywatelstwa pokonuje logikę finansowo-korporacyjną. Okazji po temu jest wiele, przypomnijmy niezwykły sukces komika Aoshimy, który wbrew naciskom i pieniądzom korporacyjnym został w 1995 roku wybrany gubernatorem Tokio po to, by wypełniając obietnicę złożoną obywatelom, odwołać niechciane przez mieszkańców World City Fair. Polskim życiem samorządowym poruszył niedawno Robert Biedroń, wygrywając w cuglach, bez partyjnego poparcia, urząd prezydenta Słupska.

Po trzecie, niezwykle istotna jest rola innego, obcego; miasto definiuje siebie wobec innego, lecz nigdy - tak jak do tej pory - przeciwko innemu. Jak czytamy u Audena, rozwój miasta i jego mentalności to nieustająca praca nad poznawaniem 
innego; tyle miejskości, ile chęci i woli do uznania, że nie wszystko odpowiada wzorom swojskiego świata. Stanowi to pierwszy krok do praktykowania polityki gościnności wobec tych-którzy-przychodzą. Miasto jest strukturą miękkiej tożsamości, jego powierzchnia nie jest już poddana obowiązkowej gładkości mapy, lecz bliższa jest złożonej i zawiłej, nakładającej się strukturze materiału pofałdowanej szaty. Kultura miasta - pisze Jacques Derrida - polega na tym, że jej własnością ,jest nie być tożsamą ze sobą. Nie tyle nie mieć tożsamości, ile nie móc się zidentyfikować, powiedzieć «ja» lub «my»”, bowiem „nie ma relacji ze sobą, identyfikacji ze soba, bez kultury, ale kultury siebie jako kultury innego, kultury różnicy względem siebie" [Derrida 2017: 16]. Z tego punktu widzenia miasto jawi się jako skomplikowana i zmienna konstelacja zmiennych formacji zawsze gotowych do przetworzeń i metamorfoz. Idąc tropem Deleuze'a, mówilibyśmy o mieście „barokowym”, w którym pofałdowana powierzchnia sprzyja kształtowaniu się ciagle nowych konstelacji. Teraz miastem „,nie jest ani określona ulica, ani dający się określić jej związek z pozostałymi ulicami, stanowiącymi jakieś stałe, lecz rozmaitość wszelkich możliwych powiązań między trasą wytyczaną przez dowolną ulicę a dowolną inną: miasto jako labirynt o uchwytnym układzie". To zaś staje się możliwe dopiero wtedy, gdy odpowiada mu stosowna postawa mieszkańca miasta. „Nieskończony ciąg krzywizn i ugięć” - kontynuuje Deleuze - „oto świat, a cały świat mieści się w duszy, włączony jest w nią z pewnego punktu widzenia" [Deleuze 2014: 57]. Miasto jest więc punktem widzenia, z którego jego mieszkańcy postrzegają przestrzeń swojego życia i usiłują się $\mathrm{z}$ nią zharmonizować.

Po czwarte, miasta wykazują skłonność do rozszerzania swego terytorium geograficznego i mentalnego. Chodzi nie tylko o to, że same miasta stają się „Metropolis", o których Auden pisze, że są miastami zbyt dużymi, zbyt wybujałymi, Metropolis, that too-great city. „Miejsko-finansowy” [Merrifield 2016: 21], jak określa to Andrew Merrifield, mechanizm funkcjonowania metropolii rozszerza się również na tereny pozamiejskie, od-kształcając narastającą mechanizacją sposoby uprawiania rolnictwa, stającego się już tylko „produkcją” żywności. Jak dowiadujemy się ostatnio, to nie imigranci są przyczyną mniejszej dostępności miejsc pracy, lecz coraz większa interwencja mechanizacji w amerykańskie farmerstwo, powodująca masowe redukcje zatrudnienia. Pamiętając o tym, powinniśmy zatem działać tak, by ocalić lokalność miasta, by jego poszczególne dzielnice zachowały swoją odrębność i specyfikę. Na tym polega zasada obrony ekscentryczności jako siły ratującej miasto.

Po piąte, formuła Miasta Błyskotek nie może wyczerpać tego, czym jest miasto. Ani polityczne mowy, ani statystyki nie dadzą nam wyobrażenia o tym, czym 
jest istota miejskości. Auden powie wprost o Metropolis: ,jej mowy nie robią na mnie wrażenia, jej statystyki jeszcze mniej mnie obchodzą". Nie powinniśmy zapominać ważnej uwagi Szekspira rozpinającej politykę między koniecznością uśpienia sumienia a skutecznie bezwzględnym dyskursem mającym narzucić obywatelom niezbędne do sprawowania władzy przekonania. Pozbywszy się etycznego namysłu, władza traktuje obywateli jako „,ciemny naród”, odrzuconą i pogardzaną ,resztę”, którą łatwo sprowadzić do poziomu zwierzęcego posłuszeństwa. Finał monologu Antonia z II aktu Burzy zwięźle ujmuje zasadę zarządzania polis, która opiera się na usunięciu etycznych motywów działania władzy politycznej oraz oszukańczej manipulacyjności dyskursu politycznego. Knujący zamach stanu dworak radzi swemu wspólnikowi: „Ty ukołysałbyś na dobre tego / Starego grzyba, Doktora Roztropka [sumienie - T.S.], / Żeby nam nie psuł szyków. Reszta łyknie, / Co im się powie, jak kot mleczko chłepce. / Tak będą tańczyć, jak im zagramy" (przeł. Piotr Kamiński).

Summa summarum wszystkie fazy opisane przez Audena zdają się kumulować w obrazie nowoczesnej metropolii, którą Manuel Castells nazywa „dzikim miastem”, a o którym Merrifield pisze, iż „rady miejskie naśladują [w nim - T.S.] zarządy korporacji; władze miejskie i państwowe dokonują outsourcingu swoich uprawnień, organizując przetargi na usługi publiczne, które wygrywają zwykle najtańsze oferty. Władze te więcej uwagi poświęcają Moody’s i innym agencjom ratingowym rodem z Wall Street niż rzeczywistym potrzebom ludzi" [Merrifield 2016: 38].

\section{7.}

Atrofia zmysłu etycznego idzie w parze z kryzysem wrażliwości estetycznej. Przed Audenem już Arthur Rimbaud przedstawi się jako ,czasowy i nie całkiem niezadowolony" obywatel metropolii (Je suis un éphémère et point trop mécontent citoyen d'une métropole crue moderne), której charakterystyczną cechą jest to, że zarówno w swej architektonice, jak i urbanistycznym zamyśle unika wszelkich znanych postaci poczucia estetycznego. Język i kod moralny zostały niejako wygładzone, ograniczone do najprostszych form, a mieszkańcy, nieodczuwający najmniejszej potrzeby wzajemnych kontaktów, przemykają wśród oparów dymu (éternelle fumée de charbon), niczym w koszmarnym Śnie Nocy Letniej. Pojawi się też przywołanie skazanej na niepowodzenie miłości (un Amour désespéré); oczywiście chodzi o coś więcej niż tylko o obraz prostytucji szalejącej w XIX-wiecznych metropoliach. Rzecz jest bardziej zasadnicza, jak wynika z lektury innego wiersza Rimbauda poświęconego miastu, w którym elementy nowocze- 
snego miasta wznoszą się na znacznie bardziej archaicznych fundamentach. Te zaś zgoła zaprzeczają coraz bardziej wymyślnej technicznie materialności cywilizacji stworzonej przez przemysłową urbanistykę. Fundamenty te znajdują się w morzu, „które w bólach rodzi wiecznie Wenus” (la naissance éternelle de Vénus), w morzu „lśniącym od pereł i osobliwych muszli”, w morzu, z którego wyjdzie Wenus, aby „nawiedzić kowali i pustelników w ich pieczarach”. Wraz z tym ruchem patronat miłości przenosi się na ląd, gdzie „Diana pierś daje swym jeleniom" i rozlega się zawodzący śpiew podmiejskich Bachantek (les Bacchantes des banlieue). Bachantki niechybnie wprowadzają nas w krag Dionizosa, który w licznych wersjach podstawowego greckiego mitu rzuca wyzwanie logice władzy i racjonalności Apolla broniącego polis przed nadchodzącym „dzikim” bogiem dalekiej prowincji. Miasto, niczym wyspa Prospera (lecz również jak dzisiejsze przedmieścia rozbrzmiewające muzyką z różnych stron świata - „Nie bój się. Wyspa dźwięczy, szemrze, gada, / Lecz śpiewa słodko, pieszcząc, a nie raniąc”, mówi Kaliban w Burzy), przeniknięte jest szczególną muzyką, a „miłosne uniesienie pędzi ulicami”. Spoglądamy na te niezwykłe obrazy nie tylko jako na przebłysk poetyckiego geniuszu, ale także jako zachętę do stawiania istotnych pytań o istotę miasta: czy można je pojmować jedynie jako materialną konstrukcję urbanistyczno-architektoniczną? Jak rozumieć dokonujące się w mieście zmiany i czy klasyczna koncepcja „postępu” stanowi tychże zmian wystarczającą wykładnię? Jak należy myśleć i przedstawiać miasto, i czy to, co filozofowie określali mianem myśli, wystarczy, by dyktować przyszłość miasta? Jakie jest miejsce emocji i wyobraźni w strukturze miasta, będącego szczytnym wykwitem zachodniej racjonalności? To tylko kilka z pytań, które powinniśmy zadać, a którym z pewnością nie podołamy w tym krótkim szkicu.

8.

Trzeba więc praktykować szczególną politykę miasta, która wobec zapewne nieuchronnego procesu rozrastania się powierzchni jego zabudowy, potrafiłaby zachować jednostkowość poszczególnych miejsc. Miasto miejsc: oto nasz program, który można by nazwać troską o miasto „w sam raz”, miasto „na miarę”. „Na miarę": czyli miasto będące konstelacją przestrzeni, które mieszkańcy zdolni są odebrać jako swoje, choć nie swoje własne, bowiem nie o własność tu chodzi, lecz o gotowość do dzielenia wspólnej przestrzeni i pracy na jej rzecz. Miasto miejsc skrojonych „na miarę” człowieka, w którym w zasięgu niespiesznego marszu odnajdzie on większość potrzebnych mu do życia rzeczy i instytucji. „W sam raz”: gdy metropolie będą się niechybnie rozrastać, życie w nich będzie 
sensowne tylko o tyle, o ile uda się zachować i zbudować terytoria zdolne do tego, by - niezależnie od rozprzestrzeniania się miasta - pozostać enklawami ludzkiej skali. Chodzi o taką organizację życia w mieście, by miejsca codziennie uczęszczane, takie jak praca, szkoła czy sklep, znajdowały się w zasięgu marszu. Miejsce to przestrzeń ani za duża, ani za mała. Miejsce jest miejscem, bowiem jest w sam raz. Aleksandra Kunce odnajduje frazę „w sam raz" w twórczości Mariusza Wilka, czyniąc z niej wyznacznik swej filozofii miejsca lokalnego: „Owo «W sam raz», gdybyśmy rozciągnęli to myślenie na «w sam raz» ludzi, ścieżek, rzeczy, myśli, zdarzeń, obcych, jest niepoliczalne, ale znaczy «tyle, ile trzeba» dla idei lokalnej. Metropolie, miasteczka i wsie mogą sprzeniewierzyć się temu, co «W sam raz». Mniej lub bardziej zakorzenione miejsce przywołuje życie «w sam raz». Ostatecznie miejsce «wejdzie nam pod skórę»" [Kunce 2016: 110]. Trzeba więc najpoważniej potraktować uwagę Marka Szczepańskiego przestrzegającego, by metropolitalne ambicje nie spełniały się kosztem miejsc. Zdaniem socjologa dzielnicowe doświadczenie (które Aleksandra Kunce nazwałaby doświadczeniem „zakorzenienia”) stanowi tożsamościową kotwicę dla wielu mieszkańców: „Dla wielu to często wyczerpujący świat. Są dom, kościół, sklep, szkoła, zakład pracy i cmentarz. Tego nie należy niszczyć, ale jednocześnie trzeba zbudować superstrukturę. Ludzie muszą na własnej skórze odczuć korzyść z istnienia metropolii” [Szczepański 2017: 11]. Problem ten trapi także Castellsa, który spogląda na dzieje nowoczesnego miasta jako na napięcie między miejscem a przepływami. $\mathrm{Z}$ jednej strony ,globalne miasto to nie miejsce, lecz proces" [Castells 2008: 390], ale przecież „ludzie nadal żyją w miejscach” [Castells 2008: 427], w które nieustannie uderzają fale przepływów. Stąd konieczność przemyślenia na nowo tego, czym jest miejsce w relacji do megapolizującego się miasta.

Dwoje śląskich autorów podsuwa nam prowizoryczna, roboczą (lecz czy może istnieć inna?) definicję miasta, które chcemy wymyślić dla naszych dzieci i wnuków: miasto miejsc, to znaczy terytoriów lokalnych, które wchodzą nam pod skórę, tworzących sieć w ramach systemu połączeń, których korzystne oddziaływanie (np. w zakresie sprawnego transportu publicznego) odczuwamy na własnej skórze.

9.

Chodzi więc o miasto jako sieć miejsc, czyli obszarów $w$ sam raz. W sam raz nawet wtedy, gdy pełzająca rozbudowa sprawiła, że miasto stało się czymś ponad miarę. Odsłania to ukrytą, lecz nadzwyczaj dynamiczną, właściwą miastu tendencję do zdradzania idei miejsca na rzecz metropolitalnej miejskości. Wtedy 
miastu przydarza się to, o czym pisze Sándor Márai, nowo przybyły do amerykańskiej metropolii emigrant: „Ludzie są czyści, ale miasto jest brudne. Jakby Nowy Jork nie potrafił się uporać z własnymi wymiarami” [Márai 2017: 213]. W refleksji o mieście należy zatem krytycznie spojrzeć na owo sprzeniewierzanie się miejscu; a sprzeniewierzenie to stanowi nieustanną pokusę dla miasta. Będzie to możliwe, gdy (a tekst Aleksandry Kunce akcentuje ten aspekt) zdamy sobie sprawę, że chodzi nie tylko o właściwą miarę i skalę rzeczy i odległości mierzalnych, ale to, co niepoliczalne, co w innym miejscu swej książki Kunce nazywa „duchową swoistością miejsca” [Kunce 2016: 165]. Swoistość ta nie jest nigdy „swojskością", bowiem w przeciwieństwie do niej nie absolutyzuje granic, choć nie kasuje ich i nie eliminuje. Dla swoistości granice pozostają, ale są granicami przenikalnymi, granicami otwartymi. Dla piszącego swój poemat w 1949 roku w spustoszonej wojną Europie Audena granica stanowiła doświadczenie bolesne i dostrzegał ją wszędzie: „Równinami,/ Między dwoma wzgórzami, dwoma wsiami, dwoma drzewami i dwoma przyjaciółmi,/ Biegnie drut kolczasty, który niczego nie tłumaczy, niczego nie wyjaśnia", i to właśnie ten znaczący granice i rozdzierający materię świata i naszego doświadczenia drut powoduje załamanie się miasta jako stylu życia i myślenia. „Tam, gdzie tylko zechce, kładzie kres miejscu, ścieżce, torom kolejowym,/ Humorowi, sztuce gotowania, rytuałom, i gustom,/ Wymazuje miasto jako wzór życia".

Duchowa swoistość miejsca polega na jego zdolności do rozcinania owego granicznego drutu, otwierania punktów przejścia. Jest tym, co wymyka się wszelkim systematyzującym stereotypom oraz bezwzględnej sile globalizującej wyglądy i charakter produktów i ludzi. Dekonstruuje władzę tego, co, zapewne za Martinem Buberem, Auden nazywa It - „to”, a co wprasowuje wszystko w przygotowane $\mathrm{z}$ góry formy oraz poddaje rzeczywistość niepodważalnym prawom przeliczalności. Posłuchajmy znów Audena: „To nie ma oblicza, które moglibyśmy podziwiać,/ Nie ma wieku, płci nie ma, ni pamięci, wiary nie ma, ani nazwiska,/ Można je policzyć, pomnożyć, zatrudnić/ W dowolnym miejscu, i unicestwić także w każdej chwili”. Wprowadza to powszechną wymienialność przedmiotów i podmiotów, których jednostkowa niepowtarzalność zostaje niemal wyeliminowana, a skoro tak, martwieje także ludzkie spojrzenie. W świecie postępującej homogenizacji przedmioty mogą być nachalnie widzialne, ale z racji braku różnic między nimi stają się właściwie niewidoczne. Nie musimy zadawać sobie trudu ich zobaczenia, bowiem jesteśmy przekonani, lub raczej - przekonano nas, że wiemy, jak one wyglądają. Tak, jakby odgradzały nas od nich mury i bariery. O mieście globalnym i kryzysie spojrzenia właściwym jego przestrzeni i dokuczającym jego 
mieszkańcom pisze Nicholas Mirzoeff: ,dawne podziały [są w nim - T.S.] wymazywane tylko po to, by stwarzać nowe. Znane nam miejsca znikają, zastępowane przez nieskończone, niemal nieodróżnialne nowe przestrzenie. Widzenie staje się skomplikowaną kwestią, bliższą wizualizowaniu pola bitwy. Musimy pamiętać, co w danym miejscu było wcześniej, próbować zrozumieć to, co znalazło się tu i teraz, i nadążyć za tempem zmian" [Mirzoeff 2016: 203].

\section{0.}

Musimy jednak bacznie uważać, by nie usunać pojęcia „granicy”, przy czym chodzi nam nie o granicę pojętą jako linia demarkacyjna oddzielająca dobrze znane od złego nieznanego, swojskie od obcego, i prewencyjnie blokującej nasze spojrzenie. Trzeba ocalić granicę jako siłę hamującą rosnącą tendencję do pełnego odkrycia, niemal obscenicznej jawności wszystkiego, co pojawia się w sferze polis. Osłabienie granicy o funkcji segregacyjnej, nie powinno oznaczać jej eliminacji jako zachowania sfery prywatności i tajemnicy. Marcel Henaff przypisuje rozkład sfery publicznej i sprzyjającej jej przestrzeni tego typu zakłóceniom spojrzenia zachodzącym w (po)nowoczesnym mieście. „Gdy wszystko można zobaczyć, znika domena należąca ściśle do tego, co widzialne. Od teraz jawność nie zna granic: zgodnie z logiką obsceniczności, działalność polityczna grzęźnie, umiejscowiona $\mathrm{w}$ jawnej sprzeczności z jej etycznymi motywacjami i zgłaszanymi przez nią samą pretensjami do odpowiedzialności" [Henaff 1996: 24]. Likwidacja granicy wstydu oznaczająca upowszechnienie prywatności sprawia, że poddana kontroli racjonalnych procedur rzeczywistość nie znajduje już miejsca dla tajemniczej sfery afektów i wyobraźni, konstytutywnej dla każdego „my”. Relegowana na głęboki margines wyobraźnia powraca i ujawnia się w zjawiskach niepokojących i groźnych, takich jak narastający nacjonalizm, rasizm, nienawiść wobec wszystkiego, co nie „nasze”. Jedyna scena, na której rozum, afekt i wyobraźnia nawiązują kontakt, to rynek i jego produkty. Zanim Eros ulegnie Thanatosowi, uzna Merkurego za swego hegemona. Henaff zauważa: „Wyobrażone i polityczne godzą się z sobą pod auspicjami rynku [...]. W ten sposób demokracja staje się nieracjonalna. Siła argumentu ustępuje przed siłą wizerunku. Debata publiczna staje się igrzyskiem" [Henaff 1996: 27]. Stawka w tej grze jest niemała. Chodzi o to, by obywatel, odzyskując siłę marzenia, utopistycznej wizji przyszłości, zdobył się na wysiłek wyrwania się z uścisku czysto rynkowej mentalności, przywracając tym samym polityce jej etyczne powinności. 
11.

Gdyby więc spytać, co stanowi bodaj najpoważniejsze zagrożenie dla miasta miejsc (zdecydowanie przedkładamy ten termin nad „metropolię”, choć zapewne ta dobrze jest utrwalona zarówno w myśleniu o mieście, jak i prawnych regulacjach kierujących jego funkcjonowaniem), trzeba by odpowiedzieć: krótkoterminowe myślenie wyswobodzone w maksymalnym stopniu z zawsze zmiennych uwarunkowań politycznych. Polityka miasta miejsc musi opierać się na zaufaniu, bowiem tylko tak możliwe jest współgospodarzenie jakimś terytorium, w którym nie zawsze można, a przede wszystkim nie zawsze trzeba odwoływać się do aktów prawnych będących dziełem i domeną władzy centralnej. Miasto miejsc jest możliwe tylko wtedy, gdy ludzie będą ufali sobie, zdając się na siebie, powierzając się sobie, a nie wszechmocnemu aparatowi państwa. Gra, jaka toczy się w miejscu, jest grą codziennego życia, czyli o świat nasz powszedni i powszechny. Nie odpowiada to pragmatyce życia politycznego, którego gra jest grą o władzę, zatem nie o świat, lecz o słuszność własnych jednostronnych racji. W znanej nam z doświadczenia polityce chodzi nie o poprawienie świata, pozostawienie go lepszym niż się go zastało, lecz o sprawowanie i utrzymanie się przy władzy (nierzadko kosztem świata właśnie; patrz polityka polskiego rządu wobec węgla i elektrowni węglowych). Dlatego polityka bycia „w sam raz” musi zakładać pewnego rodzaju „u-boczność” czy też de-centryczność wynikającą z obawy, że wszelka „centryczność” rychło uwikła się w polityczne gry. Z szacunkiem trzeba podejść do stanowiska prezydenta Jaworzna, Pawła Silberta, który deklarując, „,chcemy być na uboczu”, uzasadnia taką postawę podejrzeniem, że wobec braku strategii wieloletnich i konsekwentnych działań, niepodlegających politycznym zmianom, zależnym od bieżących układów, metropolia stanie się sceną gorszących rozgrywek między prezydentami miast. Na tej scenie, w przeciwieństwie do miasta-miejsc, nie obowiązuje zasada zaufania, co Paweł Silbert stwierdza jasno: „Podejrzewam, że najważniejsi gracze żadną miarą nie ujawnią, na co tak naprawdę liczą w związku z powstającą metropolią i wcale niemałymi pieniędzmi, które rząd obiecał na jej utrzymanie" [Silbert 2017: 15]. Retoryka doświadczonego samorządowca nie pozostawia wątpliwości: metropolia, o ile zniszczy miasto miejsc, będzie strukturą opartą na nieufności, a jej mieszkańcy będą pionkami w rękach „graczy” politycznych.

\section{2.}

Skromna i dalece niewystarczająca próba psychoanalizy miasta będzie więc skupiać spojrzenie na pojęciu granicy, tyleż niezbędnym, co niebezpiecznym. Szczególnym powodem, dla którego przywiązujemy wagę do pojęcia granicy, 
jest to, że uświadamia ona konieczność nieustającego roztrząsania miejsca i roli rozumu w procesie konstytuowania się miejskiej demokracji. Z jednej strony trzeba nieprzerwanie podkreślać racjonalną konstrukcję miejskości i jej polityk, z drugiej jednak zwracać uwagę na ustanowienie stosownej miary (by nie rzec - granicy), po przekroczeniu której rozum i jego kontrolno-dyscyplinujące praktyki zawłaszczają i kolonizują bezpardonowo sferę emocji i wyobraźni. Rola psychoanalizy polega więc na tym, że ,ustanawia ona pewne granice. Rozumu, do którego szczególnie przywiązani są filozofowie, nie można już uważać, tak jak poprzednio, za nadrzędną, autonomiczną, a nawet samowystarczalną funkcję. Argumenty, takie jak przytaczane przez Kartezjusza i Locke'a, że pojęcie myśli nieświadomej jest wewnętrznie sprzeczne, nie sąjuż tak przekonujące, jak dawniej uważano. Psychoanaliza wzbudziła powątpiewanie w prawdomówność świadomości nawet wtedy, gdy ogranicza się ona do swej własnej treści” [Hanly 2002: 311]. Owo wezwanie do pogłębionej racjonalności zdolnej wykazać powierzchowność sądów polityków, których racjonalność jest często niemal wręcz „irracjonalna”, stanowi niezwykle istotny czynnik tworzenia miasta i miejskiej obywatelskości, która powinna zachować czujność i być zawsze gotowa do powątpiewania w ,prawdomówność świadomości” politycznego świata.

\section{3.}

W elegii na śmierć Zygmunta Freuda Wystan Hugh Auden mówi o tym, że to Eros jest budowniczym miast. Eros, builder of cities - taka jest podstawa miejskości, którą projektujemy w myślach jako przyszłość nie tylko samego miasta, ale przede wszystkim ludzi miasto tworzących. Potrzebuje ono impulsywnej racjonalności lub racjonalnej impulsywności służących Oświeceniu i wykorzystujących siłę wyobraźni i popędu kierujących utopistycznym myśleniem miasta. Bez tego ugrzęźnie ono w anonimowej superstrukturze głównie ekonomiczno-administracyjnych relacji. Ostatnia strofa elegii Audena wiele nam mówi o takiej wizji miasta i o Freudzie jako jednym z jej patronów:

Zamilkł głos racjonalny: nad grobem domostwo Impulsu opłakuje drogiego zmarłego.

Smutny jest Eros, budowniczy miast,

i płacze anarchistyczna Afrodyte [Auden 1988: 111].

Oznacza to odsunięcie się od miasta jako domeny pomnażania własności i renty gruntowej. Teraz nie fascynuję się prawnym tytułem własności, doświadczam materii tego-co-jest. Andrzej Stasiuk pisze, że ludzie są wtedy „całkowicie pochłonięci materialnością świata, jego ciężarem, który sprawiał, że mogli 
odczuwać swoje istnienie jako coś realnego" [Stasiuk 2005: 52]. Eros Freuda i Eros obywatelstwa są zgoła innego rodzaju niż konsumpcyjny Eros zilustrowany z błyskotliwą ironią w kolażu Hamiltona. Afrodyta nie jest boginią bezwolnej uległości obowiązującym trendom konsumenckim; jest „anarchistyczna”, a więc dionizyjska i deliryczna w duchu Guy Deborda.

\section{4.}

W jeszcze jednym przyjdzie nam Freud z pomocą. Da nam lekcję spojrzenia na miasto, które jest dalekie od powierzchownej rejestracji jego wyglądów. W przeciwieństwie do pasywności takiej percepcji spojrzenie Freuda jest dynamiczne i tyleż zmysłowe, co wyobrażeniowe, racjonalne i impulsywne, rzeczowe i fantazmatyczne. Konstatując na początku słynnego eseju nieuchronność mechaniki ludzkiego postępowania, które w sferze miejskości zaowocuje Castellowskim miastem dzikim czy Audenowskim Miastem Błyskotek („Trudno oprzeć się wrażeniu, że na ogół ludzie posługują się w swych ocenach fałszywą miarą, starają się zdobyć dla siebie władzę, powodzenie i bogactwo..." [Freud 1967: 237]), rozważy inną możliwość, która stworzy sposobność wyjścia poza ciasne ramy, w których ludzie „nie doceniają prawdziwych wartości życia” [Freud 1967: 237]. Oto kształt owej propozycji:

Przyjmijmy teraz fantastyczne przypuszczenie, że Rzym nie jest miastem zamieszkanym przez ludzi, lecz istotą psychiczną o podobnie długiej i bogatej przeszłości, a więc istotą, w której nic nie zginęło, co choćby raz powstało, w której obok ostatniej fazy rozwoju istnieją jeszcze wszystkie fazy poprzednie [Freud 1967: 243].

Freud nazywa takie założenie fantastycznym nie tylko z racji „poetyckiego” charakteru metafory (miasto jest człowiekiem, co znajduje liczne uzasadnienia w historii literatury, by wspomnieć choćby poemat Williama Carlosa Willamsa Paterson), ale przede wszystkim dlatego, że przestrzenność miasta całkowicie wyklucza współ-istnienie różnych stadiów jego rozwoju. Inaczej niż w przypadku ludzkiej psychiki nie można mówić o historycznej wielopostaciowości miasta. Nawet jeśli przyznamy, że pewne zjawiska czy wydarzenia znikają naszej psyche, należy zauważyć, że większość z nich trwa w mniej lub bardziej uświadomionej formie. Można by zatem pokusić się o tezę, że miasto nie ma swojej podświadomości, że to, co zostaje uznane za minione, przeszłe, przepada wcześniej czy później znika w niepamięci natychmiast zastappione przez nowe konstrukcje i projekty. Oto konkluzja rozważań Freuda: „pozostaje nam zgodzić się, że zachowanie wszystkich wcześniejszych stopni rozwoju, obok formy ostatecznej, możliwe jest tylko w psychice i że nie jesteśmy w stanie unaocznić tego faktu" [Freud 1967: 245]. 
Ale zanim owa konkluzja zostanie sformułowana, filozof uraczy czytelnika niemal stronicową listą wymieniająca, paradoksalnie, to, czego nie możemy zobaczyć w Rzymie. Ulega czemuś, co sam za chwilę nazwie fantazją prowadzącą wręcz do absurdu. Nie możemy oprzeć się wrażeniu, że Freud uznaje czysto wyobrażeniowy charakter takiej operacji transformującej miasto w człowieka, ale jednocześnie nie stawia oporu przed poddaniem się jego mechanizmom. Zdaje się podsuwać nam myśl następującą: miasto nie jest ludzką psyche, ale gdyby chcieć je poznać, należałoby tak je traktować, przy czym rolę głównego instrumentu odgrywa tu wyobraźnia. Pracowałaby ona na danych dostarczonych jej przez historię, ale nie ulegając presji rzeczywistości, dokonywałaby niemożliwej operacji - umieszczałaby kilka przedmiotów w tym samym miejscu. Freud mówi o swej próbie, że to „próżna zabawa”, ale zastrzega się przed kategorycznością tego sądu; mówi - „nasza próba zdaje się być próżną zabawą”. Owo zdaje się sygnalizuje nie tylko wątpliwości nakazujące powstrzymanie się od kategorycznego sądu, ale sugeruje także, że zabawa, o której mowa, nie jest rozrywką zapełniającą czas wolny. Zdaje się Freuda wyraża zawieszenie między rzeczywistością a forma, które Schiller w Listach o estetycznym wychowaniu człowieka nazywa „wahaniem” i które opisuje jako „najwyższy stopień, do którego wzniesie się doświadczenie" [Schiller 2011:99] dostrzegające piękno w otaczającej człowieka rzeczywistości. A zatem chodzi o zabawę niebędącą do końca „zabawą”, lecz dyspozycją do dostrzegania kształtów rzeczywistości w sposób, oddajmy znów głos Schillerowi, harmonizujący materialność rzeczywistości ze zdolnością zdolną do obdarzania jej szczególną formą. Teraz miasto jest tyleż piętrzącą się konstrukcją materialnych przedmiotów i administracyjnych regulacji, co domeną kształtów nadawanym im przez doświadczające ich indywiduum. Wtedy miasto jest nasze, wchodzi nam pod skórę, jest miastem miejsc. Człowiek wtedy czuje, że żyje w mieście, tworzy je na nowo, nadając miejscom zmienne kształty i formy. Jest człowiekiem, zgodnie z tezą Schillera, że „człowiek bawi się tylko tam, gdzie w całym znaczeniu tego słowa jest człowiekiem, i tam tylko jest pełnym człowiekiem, gdzie się bawi" [Schiller 2011: 99]. W ten sposób pokonane zostaje główne zastrzeżenie Freuda, iż „ta sama przestrzeń nie jest w stanie pomieścić jednocześnie dwóch przedmiotów" [Freud 1967: 244].

Poznanie miasta, zamieszkiwanie i życie w nim w sposób prawdziwie poważny zakłada przełamanie tej zasady; wyobraźnia stawia przed nami kilka obrazów tego samego miejsca w różnym charakterze i różnej funkcji. Jak uchwycić miasto? Jak miasto ogarnąć spojrzeniem? Czy chodzi o rzut oka, czy raczej o mozolną pracę? Artyści podejmują rozmaite próby dotknięcia materialności i fizyczności miasta. Chiński performer Yin Xiuzhen przedstawia dzieło 
wystawione w Wenecji w roku 2007. Artysta prosi goszczących go galerzystów i ich znajomych w miastach, w których organizowane są jego wystawy, o zużyta garderobę. Wkłada ją do walizki i na wygładzonej powierzchni tkaniny ubrania ustawia miniaturowe budynki właściwe dla danego miasta. Colour Reading and Contexture Jacoba Dahlgrena z roku 2005 to fantazmatyczne miasto zbudowane na podłodze obszernej sali ze stosów kolorowych kartek papieru; uderza radosnym, beztroskim chaosem i feerią barw, ale jednocześnie każe zastanowić się nad ulotnością tworzywa, jakim jest papier, przypominając również o zmienności wyglądów samego miasta.

Stawkąjest więc miasto tyleż rzeczywiste, co wyobrażeniowe, choć to ostatnie określenie nie oznacza czegoś całkowicie nierealnego i wymyślonego. Miasto traktowane „osobiście” (tak nazywa Merrifield stanowisko Guy Deborda i Louisa Chevaliera) oznacza miasto nabierajace ciała, czyli jawiące się nam warstwowo i gruboziarniście. Miasto znane nam osobiście - oznaczenie to wskazuje nie tylko na mnie jako na osobę, ale przede wszystkim na miasto zyskujące osobowy status, z jego historia, widocznymi i niewidocznymi dziejami, śladami, znakami, które skryły się w podświadomości czasu. Miejsce, które wchodzi nam pod skórę, to miejsce, którego budynki i ulice kryją w sobie wiele wyglądów i przejawów życia dzisiaj już nieobecnych i niewidocznych, co nie znaczy, że nieistniejących. Jak dobitnie przekonuje Szekspirowski arcydramat, to milczący duch wprawia w ruch całą maszynerię zdarzeń, politycznych i etycznych dylematów, indywidualnych i społecznych dramatów. Kto zna niemieckie nazwy ulic Katowic, kto wie, co mieściło się niegdyś we wciąż stojących budynkach, komu nieobce są zmiany ich przeznaczenia i działalności (przykład z ostatnich tygodni - praca Hanny Baron poświęcona historii katowickich kin i sal widowiskowych), ten spowalnia proces utraty miejsc i przejmowania przestrzeni przez nieskrępowany niczym nurt przepływów.

\section{BIBLIOGRAFIA}

Arendt Hannah. 2005. Polityka jako obietnica. Przeł. W. Madej i M. Godyń. Warszawa: Prószyński i S-ka.

Auden Wystan Hugh. 1988. Poezje. Kraków: Wydawnictwo Literackie.

Auden Wystan Hugh. 1991. Collected Poems. New York: Vintage.

Benjamin Walter. 1975. Twórca jako wytwórca. Przeł. H. Orłowski i J. Sikorski. Poznań: Wydawnictwo Poznańskie.

Calvino Italo. 2009. Wykłady amerykańskie. Przeł. A. Wasilewska. Warszawa: Czuły Barbarzyńca.

Castells Manuel. 2008. Społeczeństwo sieci. Przeł. M. Marody, K. Pawluś, J. Stawiński, S. Szymański. Warszawa: Wydawnictwo Naukowe PWN. 
Deleuze Gilles. 2017. Immanencja: życie. Przeł. K.M. Jaksender. Kraków: Wydawnictwo Eperons-Ostrogi.

Deleuze Gilles. 2014. Fałda. Leibniz a barok. Przeł. M. Janik i S. Królak. Warszawa: Wydawnictwo Naukowe PWN.

Derrida Jacques. 2017. Inny kurs. Przeł. T. Załuski. Warszawa: Wydawnictwo Naukowe PWN.

Freud Zygmunt. 1967. Kultura jako źródło cierpień. Przeł. J. Prokopiuk. W: Freud Zygmunt. Człowiek, religia, kultura, 234-314. Warszawa: Książka i Wiedza.

Hanly Charles. 2002. Materializm, Humanizm i psychoanaliza. W: Psychoanaliza i kultura na progu trzeciego tysiaclecia. Przeł. A. Jankowski. N. Ginsburg i R. Ginsburg (red.), 297-317. Poznań: Rebis: Poznań.

Henaff Marcel. 1996. "The Stage of Power". SubStance. A Review of Theory and Literary Criticism XXV(2): 20-36.

Kunce Aleksandra. 2016. Człowiek lokalny. Rozważania umiejscowione. Katowice: Wydawnictwo Uniwersytetu Śląskiego.

Lukács György. 1968. Teoria powieści. Esej historyczno-filozoficzny o wielkich formach epiki, przeł. J. Goślicki. Warszawa: PWN.

Mann Thomas. 2016. Czarodziejska góra. Przeł. J. Kramsztyk i J. Łukowski. Warszawa: Muza.

Márai Sandor. 2017. Dziennik. 1949-1956. Przeł. T. Worowska. Warszawa: Czytelnik.

Merrifield Andrew. 2016: Nowa kwestia miejska. Przeł. P. Juskowiak. Warszawa: Wydawnictwo Naukowe PWN.

Mirzoeff Nicholas. 2016. Jak zobaczyć świat. Przeł. Ł. Zaręba. Wydawnictwo Karakter: Kraków-Warszawa: Karakter.

Schiller Friedrich. 2011. Pisma teoretyczne. Przeł. J. Prokopiuk. Warszawa: Aletheia.

Silbert Pawel. 2017. „Chcemy być na uboczu” (Miasta idei Kwartalnik samorządowy) Gazeta Wyborcza, 31.03, 15-16.

Stasiuk Andrzej. 2005. Dukla. Wołowiec: Wydawnictwo Czarne.

Szczepański Marek. 2017. ,Jesteśmy spóźnionym przybyszem” (Miasta idei. Kwartalnik samorządowy) Gazeta Wyborcza, 31.03, 10-12.

Tadeusz Stawek

\title{
JUST WHAT IS IT THAT MAKES TODAY'S CITIES SO DIFFERENT, SO APPEALING? THE POSTMODERN URBANITY
}

\begin{abstract}
Starting with Richard Hamilton's famous collage and W.H. Auden's poetic rendition of the history of cities, we argue that what the Greeks called polemos has been the very element of urbanity. The conflict could imply tensions between the rich and the poor, aristocrats or the hoi polloi, but we have reached the stage at which such a rigorously dichotomic vision of the conflict does not provide one with an appropriate approach towards the phenomenon of urbanity.

The model of binary oppositions should be supplanted by a much more diverse scheme which would allow for the integration of such elements as affects, desires, and dreams, the factors which do not readily succumb to dialectical analysis. Hence, following Deleuze, Merrifield, and Debord, we want to see the city as an intricate structure of many-layered elements, both physical and imagined.
\end{abstract}

Keywords: city, rationality, affect, imagination, play 